\title{
New Solpugids (Arachnida:Solpugida) from Puerto Rico ${ }^{1}$
}

\author{
Marlin H. Muma and Maria Luisa Nazario²
}

\section{INTRODUCTION}

No species of solpugid has been reported previously from Puerto Rico in the literature $(1,2,4,5,6) .^{3}$ The two species described below thus are important historically as the first records of the order from the Island. One of these, Ammotrechella pallida, is the first new species of the order collected from the Caribbean area in over 35 years.

One specimen of Ammotrechella pseustes (Chamberlin), a female, constitutes a new record for the Antilles. Owing to its scientific and historic importance, the species is redescribed here.

\section{DESCRIPTION OF SPECIES}

\section{Genus Ammotrechella Roewer}

Ammotrecha Banks, 1900: 426 (in part).

Ammotrechella Roewer, 1934: 595, Mello-Leitaõ, 1938: 22; Muma, 1951: 125; Muma, 1970: 45.

GENEROTYPE: Gluvia geniculala Koch, 1842 by designation of Roewer in 1934 .

Ammotrechinae in which ventral spinelike setae on tarsi of legs 2 and 3 are arranged 1,2,2,1 and those on tarsi of leg 4 are arranged 2,-2-2-2-. Chelicerae have two anterior teeth on fixed finger and mesal tooth on movable.

Male characters have not been evaluated.

When Roewer (5) erected this genus, he included A. hubneri (Kiraepelin) and $A$. diaspora Roewer along with the generotype. Muma ( 3 ) assigned three additional species from the United States to the genus and later (4) recognized six species from North America, Central America, and the West Indies. South American species, the new species described below, and an undescribed species from Jamaica raise the number of known species to 10. Diagnostic characters and distribution of the described species are compared in table 1.

With the exception of $A$. diaspora, described from the Cape Verde Islands, the genus is distributed throughout southern North America,

1 Florida Agricultural Experiment Station, Journal Series No. 3685.

2 Entomologist, University of Florida Citrus Experiment Station, IFAS, Lake Alfred, Florida 33850, and Rescarch Assistant, Enlomological Pioneering Research Laboratory, Cniversity of Puerto Rion at Mayngüez, Mayagüez, P. R.

3 Italic uumbers in parentheses refer to literature Cited, p. 512. 


\begin{tabular}{|c|c|c|c|c|c|}
\hline \multirow{2}{*}{ Species } & \multirow{2}{*}{ Geographic distribution } & \multicolumn{2}{|c|}{$\begin{array}{l}\text { Spinelike setation on palpal } \\
\text { metatarsus }\end{array}$} & \multicolumn{2}{|l|}{ Dusky coloration } \\
\hline & & $\sigma^{2}$ & 9 & Palpal segments & Abdominal stripes \\
\hline 1. 1. pallida new species & Puerto lieo & None & None & None & None \\
\hline 2. A. setulosa Mluma & Texas & & $2 \mathrm{pr} . \mathrm{d} 1-2 \mathrm{extrn}$ & $\begin{array}{l}\text { Anuulate middle all seg- } \\
\text { ments }\end{array}$ & $\begin{array}{l}1 \text { broad median } \\
2 \text { narrow lateral }\end{array}$ \\
\hline 4. A. geniculata (Koch) & $\begin{array}{l}\text { Curacao } \\
\text { Venezuela } \\
\text { Colombia } \\
\text { Ecuador } \\
\text { St Vincent } \\
\text { Guadeloupe } \\
\text { Bahama }\end{array}$ & 6 pr. & $3 \mathrm{pr}$. & Tarsus, metatarsus \& tibia & 2 narrow lateral \\
\hline 5. A. bolivari Mello-Leitaō & Mexico & & $5 \mathrm{pr}$. & Tarsus and metatarsus & 1 broad median \\
\hline 6. .1. slimpsoni (Putuam) & Florida & $5 \mathrm{pr}$. & $5 \mathrm{pr}$. & $\begin{array}{l}\text { Tarsus, metatarsus tibia d } \\
\text { apical end of femora }\end{array}$ & 2 narrow lateral \\
\hline 7. A. diaspora Roewer & $\begin{array}{l}\text { Cape Verde Is- } \\
\text { lands }\end{array}$ & & $7 \mathrm{pr}$ & None & None \\
\hline 8. A. Labogana & $\begin{array}{l}\text { Panamá, Canal } \\
\text { Zone }\end{array}$ & & $\begin{array}{l}2 \text { rows of } 10 / 14 \\
\text { stoma cylinder } \\
\text { bristle }\end{array}$ & $\begin{array}{l}\text { Tarsus, metatarsus tibia d } \\
\text { apical end of femora }\end{array}$ & 2 narrow lateral \\
\hline 9. A. hubneri (F̈ruepelin) & Venezuela & & $\begin{array}{l}1 \text { basal \& } 1 \text { apical } \\
\text { unpaired }\end{array}$ & $\begin{array}{l}\text { Tarsus and apical end of } \\
\text { metatarsus }\end{array}$ & 1 broad median \\
\hline
\end{tabular}


Central America, the West Indies, and northern South America and is restricted apparently to this region.

A mmotrechella pseusles (Chamberlin) (Redescription)

(Figs. 1 to 3 )

Ammotrecha pseustes Chamberlin, 1925: 235; Muma, 1970: 470.

Ammotrechella sexspicala Muma, 1951: 129.

FEMales: Total length, $12.6-14.0 \mathrm{~mm}$; Chelicerae, $1.3-1.3 \mathrm{~mm}$. wide and 3.7-3.9 mm. long; Propeltidium, 2.6-2.7 mm. wide and 2.1-2.3 mm. long.

Coloration in alcohol white to light yellow with dark to dusky brownishpurple markings as follows: eye tubercle dark; propeltidium dusky brown with narrow submarginal band and fine pale stripe extending from eye tubercle to posterior margin; chelicerae pale except for dentition, carina, and pair of faintly dusky dorsal stripes; meso- and metapeltida dusky laterally; abdominal tergites pale medially and dark laterally forming two dark longitudinal stripes; abdominal segments laterally lightly dusky, ventrally pale. Palpi dark in tarsi, metatarsi, tibiae, and apical ends of femora; coloration interrupted with pale below on femora and tibiae. Legs 1, 2, and 3 essentially pale but faintly dusky on femora and tibiae of leg 3. Some specimens have legs 2 and 3 with markings similar to those cited here for leg 4 . Leg 4 dusky on femora, tibiae, and metatarsi but interrupted with pale dorsally and ventrally. Malleoli light.

Dentition typical of Ammotrechinae and as shown in figure 1. Peak of dorsal carina occurs above first fondal tooth of ectal row. There is a distinct mesal tooth.

Palpus clothed with usual long and short setae, and scattered cylinder bristles; metatarsus with three pairs of small stout spinelike setae as shown in figure 2; femur and tibia apparently without serially arranged spinclike setae.

Chelicerae about three times as long as wide. Propeltidium wider than long by ratio of 1.0 to 1.2. Eyes about one diameter apart. Genital plate typical as shown in figure 3 , and wider than long by ratio of 1.0-1.5 to 1.01.7.

MALE: Unknown.

TYPE LOCALITY: Female holotype from nest of Kalotermes marginipennis on Remo Island, Largo, Canal Zone, August 31, 1923 by James Zetek.

TYPE: In the Museum of Comparative Zoology, Harvard University. Cambridge, Massachusetts.

NEW RECond: Female from Peñuelas, Puerto Rico, March, 1968 by Diego Mejía. 
This is the only known species of the genus with three pairs of spinelike setae on the palpal metatarsi and distally dark palpal femora. Ammotrechella geniculata (Koch), according to Roewer (5), has similar female palpal armature but the palpal femora are pale and the dorsal cheliceral carina is limited to the apical half of the fixed finger.

This species is now known from the Panama Canal Zone, California, and Puerto Rico.

\section{Ammoliechella pallida new species}

\section{(Figs. 4 to 9 )}

MaLe holotrpe: Total length $11.0 \mathrm{~mm}$. Chelicerae $0.9 \mathrm{~mm}$. wide and $2.9 \mathrm{~mm}$. long. Propeltidium $2.2 \mathrm{~mm}$. wide and $2.1 \mathrm{~mm}$. long.

Coloration in alcohol light-yellow with no markings except for greyish tinge on abdominal tergites and sternites, dark-brown to black eye tubercle, and usual reddish-brown color of cheliceral fingers and dentition. Peltidial and cheliceral spinelike setae brownish-yellow in color and distinct against pale background.

Dentition as shown in figures 7 and $S$. Fixed finger slightly constricted dorso-ventrally just behind two anterior teeth which are distinctly separated from intermediate and principal teeth; intermediate tooth arises on anterior margin of principal tooth. Intermediate tooth of movable finger closer to principal tooth than to anterior tooth. Mesal tooth distinct. Flagellum elliptical but with forward projection distinctly narrowed and more distinctly fringed than posterior portion.

Palpus lightly clothed with usual long setae, short setae, and cylinder bristles, latter slightly longer and more dense on the ventral surface. There are no distinguishable spinelike setae on palpal metatarsi as shown in figure 9 but there are five distinct pairs on tibiae and one or two indistinct unpaired on femora.

Chelicerae about three times longer than wide. Propeltidium wider than Jong by ratio of 1.1 to 1.0. Lyes slightly less than a diameter apart.

FEMALES: Total length 14.5 to $20.0 \mathrm{~mm}$. Chelicerae 1.3 to $1.7 \mathrm{~mm}$. wide and 3.6 to $4.0 \mathrm{~mm}$. wide and 2.3 to $2.8 \mathrm{~mm}$. long. Allotype larger measurements.

Coloration in alcohol similar to that of male: white to light yellow except for greyish tinge on abdominal tergites and pleurites, and usual reddishbrown color of cheliceral fingers and dentition.

Dentition typiral of Ammotrechinae and as shown in figure 4. Peak of carinat occurs above principal tooth of fixed finger. Both fixed and movable finger exhibit only one intermediate tooth located at base of or on anterior margin of principal tooth. Mesal tooth present but small and indistinct. 


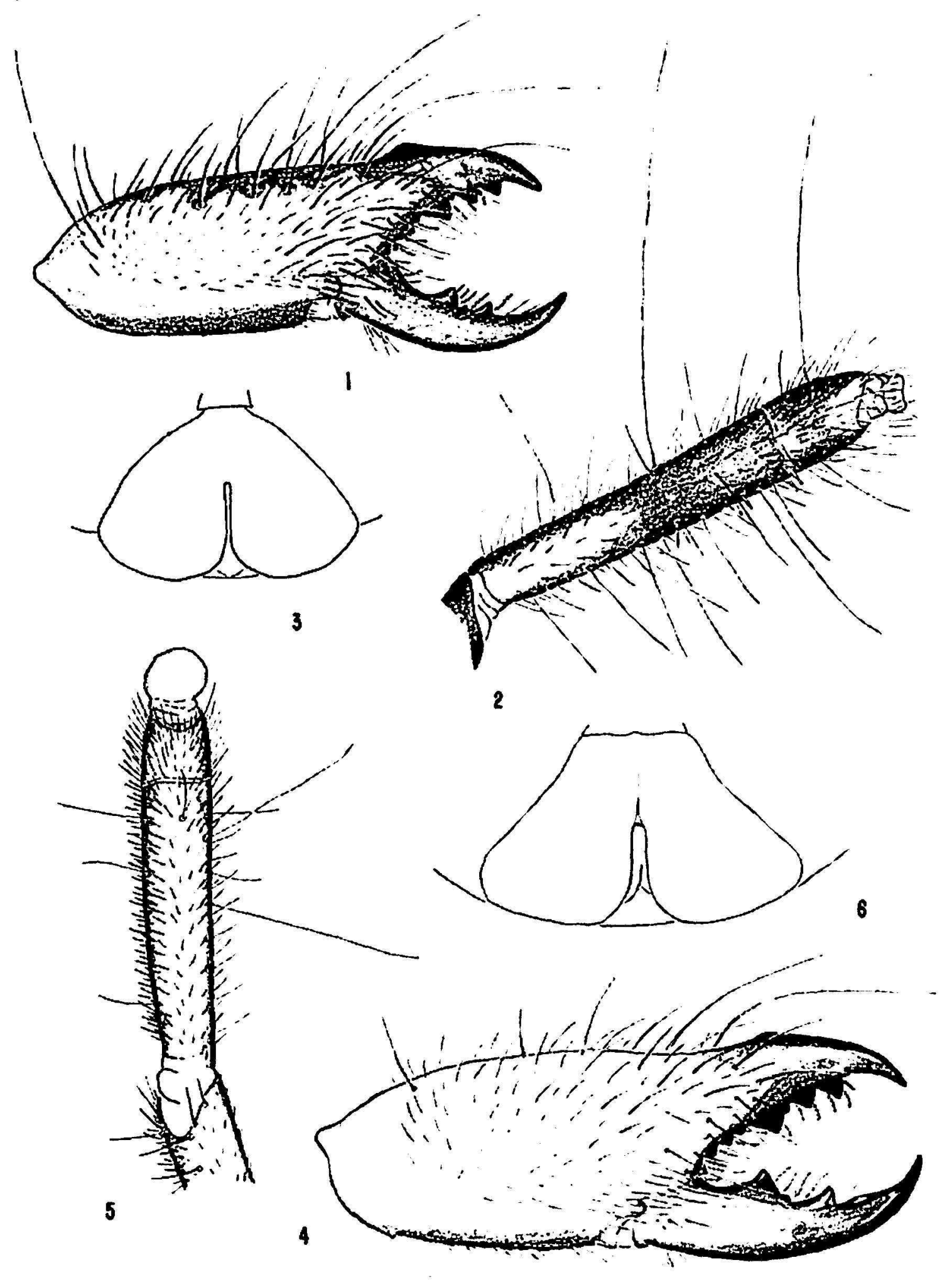

Figs. 1 to 3. 1mmotrechella pseustes Chamberlain. 1, Right female chelicera, ectal view. 2, left female palpus, mesovent ral view. 3, Female opereula.

Firis. +10 ti.-Ammotrechella pallida new species. 4 , Right female chelicerae, ectal view. 5, light female palpus, mesoventral view. (i, fomale opereulat. 
Palpus lightly clothed with usual long setae, short setae, and cylinder bristles as shown in figure 5; there are no distinguishable strong stout spinelike setae on metatarsi, but there are five pairs of barely distinguishable, elongate spinelike setae on tibiae, and two or three unpaired spinelike setae on femora.

Chelicerae about 2.8 times longer than wide. Propeltidium wider than long by ratio of 1.4 to 1.0. Eyes about one diameter apart. Genital plate typical as shown in figure 6, and wider than long by ratio of 1.4 to 1.0.

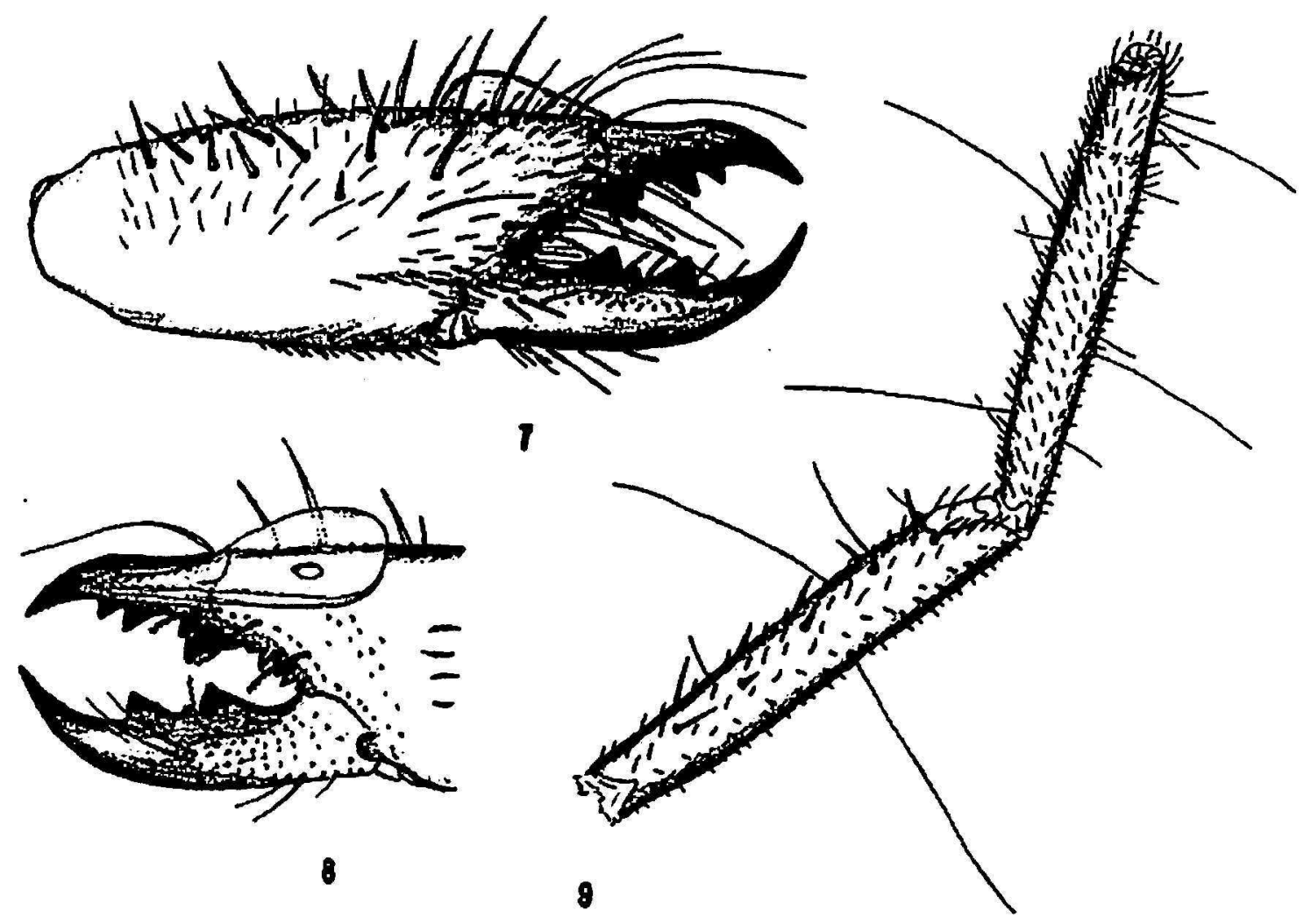

Figs. 7 to 9.-Ammotrechella pallida new species. 7 , Right male chelicerne, ectal view. 8, light male chelicerae, mesal view. 9, Left male palpus, mesovent ral view.

TYPE LOCALITY: Male holotype collected in can trap in Bosque Guánica, Puerto Rico between September 9 and 23, 1969 by María Luisa Nazario. Female allotype and female paratype with same collection data between June 1 and 15, 1969 by Martin H. Muma and María Luisa Nazario. Female paratype with same collection data between July 1 and 15, 1969 by Maria Luisa Nazario. Female paratype with same collection data between May 9 and 23, 1970 by María Luisa Nazario.

Trpls: Deposited in the American Museum of Natural History, New York, New York.

This is the only known pale species with unarmed palpal metatarsi in 
the subfamily. It is, therefore, distinctive regardless of the validity of tarsal setal formulae as generic diagnostic characters.

\section{SUMMARY}

Two species of solpugids are recorded from Puerto Rico for the first time: Ammotrechella pseustes (Chamberlin) from Peñuelas and Ammotrechella pallida, new species, from Bosque Guánica. A tabular key to known species of the genus is included.

\section{RESUMEN}

Se informan dos solpúgidos encontrados por primera vez en Puerto Rico: Ammotrechella pseustes (Chamberlin) en Peñuelas y Ammotrechella pallida, una nueva especie, en el Bosque de Guánica. También se incluye una clave taxonómica para identificar las especies conocidas de ese género.

\section{LITERATURE CITED}

1. Koch, C. L., Systematische Uebersicht uber die Familie der Galeoden, Arch. Naturgesch 1: 350-56, 1842.

2. Kraepelin, K., Palpigradi und Solifugae, In Das Tierreich. Leipzig, Deutsche Zoologischer Gesellschaft 12: 1-159, 1901.

3. Muma, Martin H., The arachnid order Solpugida in the United States, Bull. Amer. Mus. Hisi. 97 (2): 31-142, 1971.

4. Muma, Martin H., A synoptic review of North American, Central American, and West Indian Solpugida (Arthropoda:Arachnida), Arthropods of Florila and Neighboring Land Areas 5 : 1-62, 1970.

5. Roewer, C. F. R., Solifugac, Palpigradi, In Bromn, II. G., Klassen und Ordnungen des Tierreichs, 5 , div. 4, book 4:1-723, 1934.

6. Simone, Eugene, Essai d'une classification des (ialeodes, Ann. Soc. Ent. France, Ser. $V, 9: 93-154,1879$. 